\title{
Croatian Web Dictionary - Mrežnik vs. Croatian Linguistic Terminology - Jena
}

\author{
Lana Hudeček \\ Institute of Croatian Language and Linguistics, Zagreb, Croatia \\ lhudecek@ihjj.hr \\ Milica Mihaljević \\ Institute of Croatian Language and Linguistics, Zagreb, Croatia \\ mmihalj@ihjj.hr
}

\begin{abstract}
Summary
The Croatian Web Dictionary - Mrežnik is a four-year project which started on the $1^{\text {st }}$ of March 2017 and the duration of the project is four years. The main result of the project will be a free, monolingual, hypertext online dictionary consisting of three modules (the module for adult native speakers - 10,000 entries, the module for children aged 6 to 10-3,000 entries, and the module for non-native speakers learning Croatian - 1,000 entries). Mrežnik is based on two Croatian web corpora. Croatian Linguistic Terminology - Jena is a new terminological project conducted within the Struna program. The project started on the $24^{\text {th }}$ of May 2019 and lasts until the $23^{\text {rd }}$ of November 2020. The main result of the project will be a multilingual database consisting of 1,500 entries. As a specialized corpus of Croatian linguistic terminology doesn't exist, it is compiled in parallel with the database. Although Mrežnik and Jena differ in their basic goals and approach; one is monolingual and general and the other is multilingual and specialized (terminological), one is compiled from the existing corpora and the other is compiled in parallel with the corpus, they have two important meeting points: 1. General linguistic terminology is presented in Mrežnik (mostly but not exclusively in the module for adult native speakers) and 2. Within the Mrežnik project, Glossary of Elexicographic terminology is compiled. These four parameters will be compared: 1. wordlist/termlist, 2. relation to the corpus, 3. giving normative information, 4. entry structure. The compilation process and the structure of entries for the same headword will be compared and the important similarities, as well as differences, will be shown. The reason for this comparison is that the two projects are conducted at the same time and strongly influence each other in many aspects.
\end{abstract}

Key words: Mrežnik, Croatian Linguistic Terminology - Jena, linguisitic terminology, elexicography

\section{Introduction}

The project Croatian Web Dictionary - Mrežnik ${ }^{1}$ aims at creating a free, monolingual, easily searchable hypertext online dictionary of standard Croatian. It will be the first web-born dictionary of the Croatian language. Entries, sub-entries, and meanings will be interconnected, as well as linked to entries in databases created within the framework of the project in parallel with the creation of the dictionary (language advice database, conjunction database with description of groups of conjunctions and their modifiers, database of explanations of the origin of idioms, database of ethnics and ktetics), as well as databases being created by project collaborators or other Institute members within the framework of other projects. ${ }^{2}$ Mrežnik consists of three modules: the module for adult native speakers of Croatian which will have 10,000 entries, the module for school children which will have 3,000 entries, and the module for non-native speakers which will have 1,000 entries). The dictionary is written in the TLex program, which has been adapted to the needs of the project. The main goals of the project are: 1 . to create the three dictionary modules, 2 . to connect the dictionary with the databases created in parallel with the dictionary, 3. to connect the dictionary with other web sources currently being compiled at the Institute of Croatian Language and Linguistics, 4. to compile a reversed dictionary based on the Mrežnik wordlist, 5. to write a monograph on Mrežnik. The project

\footnotetext{
${ }^{1}$ More on Mrežnik see in Hudeček 2018; Hudeček, Mihaljević 2017a, 2017b; Hudeček, Mihaljević, 2018a, $2018 b$.

${ }^{2}$ More on this topic see in Hudeček, Mihaljević 2019a.
} 
started on the $1^{\text {st }}$ of March 2017, so at the moment we are in the second half of the project and more than 5,000 entries have been compiled.

The project Croatian Linguistic Terminology - Jena is conducted within the Struna program. Struna is a database of Croatian Special Field Terminology ${ }^{3}$ financed by the Croatian Science Foundation. Jena is a year-and-a-half project which started on the $24^{\text {th }}$ of May 2019. The main goals of the project are: 1. to compile 1,500 entries with definitions, synonyms, antonyms, hyponyms and equivalents in English, German, French, Russian, and Swedish in the Struna database, 2. to collect works on linguistic terminology and present them on the Jena website (ihjj.hr/jena/), 3. to write a monograph on Croatian linguistic terminology. At the moment 1035 entries have been entered into the database. However, it is important to note that both Croatian Web Dictionary-Mrežnik and Jena are conceived as a dynamic dictionary/databases that will be further compiled and edited even after the formal end of the project funding and will not reach their full extent if they do not continue to grow and become an everlasting project of the Institute.

\section{Hypothesis and reason for comparison}

The hypothesis of this paper is that although a terminological database obviously differs from a general e-dictionary there are many similarities from which both projects can profit.

The reason for such a comparison is that these two projects are conducted at the same time in the same institution, the head of Mrežnik (Lana Hudeček) is the collaborator of Jena while the head of Jena (Milica Mihaljević) is the collaborator of Mrežnik. Thus some results of one project can be applied to the other and vice versa. In the comparison all linguistic terms which appear in Mrežnik ${ }^{4}$ and the Glossary of e-lexicographic terminology compiled within the Mrežnik project are taken into account. As both projects are in progress the instructions for the respective team of lexicographers and terminographers can be modified according to new results. The basic points of comparison are: 1 . the ways of compiling wordlist/termlist, 2. the approach to the corpus, 3. the approach to normativity, 4 . the structure of dictionary entries.

\section{Wordlist vs. termlist}

To compile the Mrežnik wordlist the frequency lists of $h r W a C$ (first 12,000 words) and the Hrvatska jezična riznica (first 10,000 words) were overlapped, all words present only in Hrvatska jezična riznica and not present in $\mathrm{hrWaC}$ were extracted, their frequency was multiplied by four, and they were added to the shared list. This wordlist (first 8,000 entries) was juxtaposed with two separate wordlists: the wordlist for the module for children (which was excerpted from textbooks for the first four grades of elementary school with some additions by the collaborators of Mrežnik) and the wordlist for the module for non-native speakers which includes 1,000 words taken from a list in textbooks for non-native speakers, to ensure that words found in both these lists (which partially overlap) appear in the list for adult native speakers. This wordlist was supplemented with male/female (in cooperation with the project Male and Female in the Croatian Language) and aspectual pairs, possessive and descriptive adjectives, adverbs derived from adjectives from the list, nouns ending in ost derived from adjectives from the list, numerous grammatical and semantic groups, etc. This resulted in a wordlist of 10,000 words with two separate wordlists of 3,000 words (for children) and 1,000 words (for non-native speakers).

The wordlist of the module for children was considered as the basic wordlist and we first began compiling the entries for words from this list in order to make processing for the module for children as compatible as possible with that for adult native speakers (Hudeček, Mihaljević, 2018b).

\footnotetext{
${ }^{3}$ The Institute of Croatian Language and Linguistics was chosen to serve as the national coordinator. The objective of the program in a broader sense is to lay the foundation for the development of national terminology policy, to establish various forms of more structured education in this field, and to intensify long-term cooperation with national and international academic and other institutions dealing with different aspects of terminology work, with the Croatian Standards Institute and with other interested parties. Within the program, a terminology database has been developed to store and terminographically manage standardized and harmonized Croatian terms from various subject fields and their equivalents in English and other languages. Experts from eighteen domains have so far joined the program with the aim of standardizing the terminology of their respective disciplines. http://struna.ihjj.hr/en/about/.

${ }^{4}$ Of course some linguistic terms have a non-linguistic meaning which occurs in Mrežnik and doesn't occur in Jena but this was not the subject of our analysis.
} 
The Jena termlist consisting of 1,500 terms was compiled by project collaborators divided into workgroups by subject fields: basic linguistic terminology, cognitive linguistics, contact linguistics, dialectology, e-lexicography and corpus linguistics, generative linguistics, glottodidactics, language history, lexicography, lexicology, onomastics, orthography, phraseology, pragmatics, sociolinguistics, terminology, translation theory, valency theory. Table 1 shows a small extract from the termlist divided by subject fields.

Table 1. Extraction of Jena termlist by specialized subject fields

\begin{tabular}{|c|c|c|c|c|}
\hline $\begin{array}{l}\text { 1.1 Generative } \\
\text { linguistics }\end{array}$ & $\begin{array}{l}\text { 1.2 Cognitive } \\
\text { linguistics }\end{array}$ & 1.3 Phraseology & $\begin{array}{l}4 \text { Translation } \\
\text { leory }\end{array}$ & $\begin{array}{l}5 \text { Language } \\
\text { istory }\end{array}$ \\
\hline $\begin{array}{l}\text { 1.6 E-jezik } \\
1.7 \text { generativna } \\
\text { gramatika } \\
1.8 \text { I-jezik } \\
1.9 \text { jezična moć } \\
1.10 \text { jezična } \\
\text { sposobnost } \\
1.11 \text { jezična } \\
\text { uporaba } \\
1.12 \text { logički } \\
\text { problem jezičnoga } \\
\text { usvajanja } \\
1.13 \text { negativni } \\
\text { dokazi } \\
1.14 \text { objasnidbena } \\
\text { prikladnost } \\
1.15 \text { opisna } \\
\text { prikladnost } \\
1.16 \text { oskudnost } \\
\text { poticaja } \\
1.17 \text { pozitivni } \\
\text { dokazi }\end{array}$ & $\begin{array}{l}1.18 \text { apsolutni } \\
\text { prostorni sustav } \\
1.19 \text { apstrahiranje } \\
1.20 \text { argumentna } \\
\text { struktura } \\
1.21 \text { asimetrija } \\
\text { izvornoga i ciljnoga } \\
\text { okvira } \\
1.22 \text { automatsko } \\
\text { prepoznavanje } \\
\text { metafora } \\
1.23 \text { autonomistički } \\
\text { gramatički pristup } \\
1.24 \text { konceptualne } \\
\text { integracije } \\
1.25 \text { ciljna domena } \\
1.26 \text { dinamični } \\
\text { razvojni model } \\
1.27 \text { dinamika sile } \\
1.28 \text { diskursna } \\
\text { analiza vođena } \\
\text { metaforom }\end{array}$ & $\begin{array}{l}1.29 \text { frazeologija } \mathrm{u} \\
\text { užemu smislu } \\
1.30 \text { frazeologija } \mathrm{u} \\
\text { širemu smislu } \\
1.31 \text { paremiologija } \\
1.32 \text { krilatologija } \\
1.33 \text { zoonimna } \\
\text { frazeologija } \\
1.34 \text { somatska } \\
\text { frazeologija } \\
1.35 \text { internacionalna } \\
\text { frazeologija } \\
1.36 \text { nacionalna } \\
\text { frazeologija } \\
1.37 \text { posuđena } \\
\text { frazeologija } \\
1.38 \text { arhaična } \\
\text { frazeologija } \\
1.39 \text { dijalektna } \\
\text { frazeologija } \\
1.40 \text { regionalna } \\
\text { frazeologija } \\
1.41 \text { frazeološki } \\
\text { obrat }\end{array}$ & $\begin{array}{l}\text { 1.42 automatsko } \\
\text { prevođenje } \\
1.43 \text { doslovno } \\
\text { prevođenje } \\
1.44 \text { književno } \\
\text { prevođenje } \\
1.45 \text { komunikacijski } \\
\text { model prevođenja } \\
1.46 \text { ljudsko } \\
\text { prevođenje } \\
1.47 \text { pismeno } \\
\text { prevođenje } \\
1.48 \text { simultano } \\
\text { prevođenje } \\
1.49 \text { slobodno } \\
\text { prevođenje } \\
1.50 \text { strojno } \\
\text { prevođenje računalno } \\
\text { prevođenje } \\
1.51 \text { traduktologija } \\
1.52 \text { univerzalni } \\
\text { prevodilac }\end{array}$ & 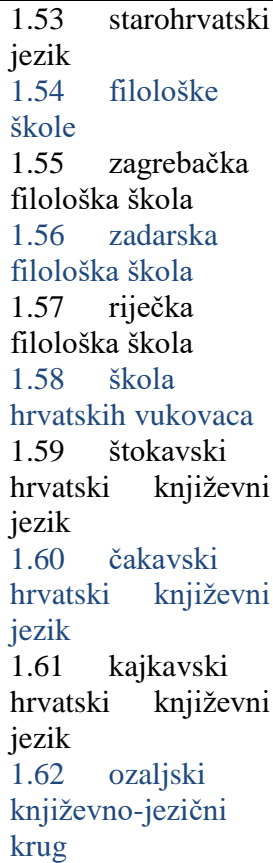 \\
\hline
\end{tabular}

These terms will not appear as headwords of entries or subentries in Mrežnik. However, terms belonging to basic linguistic terminology and orthography will appear in Mrežnik as well as in Jena. Some terms belonging to basic linguistic terminology are shown in the text bellow. Figure 1 shows an extraction of the wordlist in Jena.

\begin{tabular}{|l|l|l|l|}
\hline infinitiv & jezikoslovlje & filologija & $\begin{array}{l}\text { opće jezikoslovje } \\
\text { (lingvistika) }\end{array}$ \\
\hline imperfekt & jezikoslovlje & filologija & $\begin{array}{l}\text { opće jezikoslovlje } \\
\text { (lingvistika) }\end{array}$ \\
\hline imperativ & jezikoslovlje & filologija & $\begin{array}{l}\text { opće jezikoslovje } \\
\text { (lingvistika) }\end{array}$ \\
\hline imenica & jezikoslovje & filologija & $\begin{array}{l}\text { opće jezikoslovje } \\
\text { (lingvistika) }\end{array}$ \\
\hline
\end{tabular}

Figure 1. General linguistic terminology from Jena

These linguistic terms will also be entries in Mrežnik.

\section{Corpus-based}

Both Mrežnik and Jena are corpus-based, and not corpus-driven. This means that the corpus and all data extracted from it serve only as guidelines. The Glossary of E-lexicographic Terminology on the Mrežnik website ihjj.hr/mreznik defines a corpus-based dictionary as follows: a dictionary for which the lexicographer uses a corpus, but can freely decide what should be included in the dictionary, 
allowing the dictionary to be supplemented with words from other sources if necessary, as well as collocations and meanings not attested in the corpus. The reason for this approach is that neither of the corpora on which Mrežnik is based (Croatian Web Repository online corpus (riznica.ihjj.hr/index.hr.html) and Croatian web corpus - hrWaC (nlp.ffzg.hr/resources/corpora/hrwac/) are representative of the Croatian language ( $\mathrm{hrWaC}$ is primarily based on the colloquial and journalist style and Croatian Web Repository on the literary style), they are not corpora of the standard language nor are they balanced corpora. It follows that, in composing an entry, lexicographers can add meanings to a particular entry or to the collocation field even if they do not appear in the corpus.

Data extraction from the corpora for Mrežnik as well as for Jena is performed with the SketchEngine web tool, which allows the display of lexeme context through WordSketches, the most common collocations sorted into syntactic categories and the discovery of good examples of word usage or collocations. After lexicographic processing of Mrežnik is completed, the data will be exported from TLex to the web application and the CLARIN European science infrastructure repository (clarin.si repository and the github.com public data management system). This will make Mrežnik available for use both via a web application and for machine implementation by downloading data from the CLARIN repository.

Jena is based on the corpus Jezikoslovlje composed specially for the needs of the project. It consists of a corpus of linguistic papers and monographs compiled under SketchEngine. The Jena corpus which has been compiled by project members and collaborators is the corpus of standard language (in the field of linguistics) but it is as yet not representative enough. Moreover, on many modern linguistics topics there are not many texts in Croatian and many Croatian terms have to be coined by the authors (specialists of the particular linguistic field) themselves. From this corpus a term list has been compiled which contrasted the words appearing in the corpus with the words from $h r W a C$. The basic term list is still the one created by project collaborators but it will be checked against the one created by Sketch Engine from the corpus so Jena will also be corpus-based. The Jena corpus is also helpful when creating definitions and deciding on the normative status of synonymous words.

\section{Normativity}

The Croatian Web Dictionary - Mrežnik is a normative dictionary and Jena is a normative terminological database. The normative nature of Mrežnik is apparent in the following: 1. the selection of entry-words, 2. giving normative advice in all three modules, 3 . the selection of forms acceptable by the standard language norm in the grammatical block, 4. the selection of examples (the dictionary collaborators try to select examples with no language errors while examples with language errors are edited), 5. the accentuation of entry-words and forms in the grammatical block according to the standard language norm.

The most important normative aspect of Jena is differentiating between the preferred, allowed, nonpreferred, obsolete, and jargon terms (as will be shown in the examples below). If needed normative advice is given in the field note, e.g. why the preferred term is točka sa zarezom and not tocka-zarez as shown in table 2.

\section{Word entries vs. term entries}

Two important meeting points of Mrežnik and Jena are 1. General linguistic and orthographic terminology is presented in Mrežnik and 2. Within the Mrežnik project, a Glossary of E-lexicographic Terminology is compiled (ihjj.hr/mreznik/page/pojmovnik/6/).

\section{General orthographic terminology in Mrežnik and Jena}

Table 2 illustrates the structure of the entries točka (period) and točka sa zarezom (semi-colon) in Jena and compares them to the respective entry or subentry in Mrežnik: 
Table 2. Entries točka (period) and točka sa zarezom (semicolon) in Jena and Mrežnik

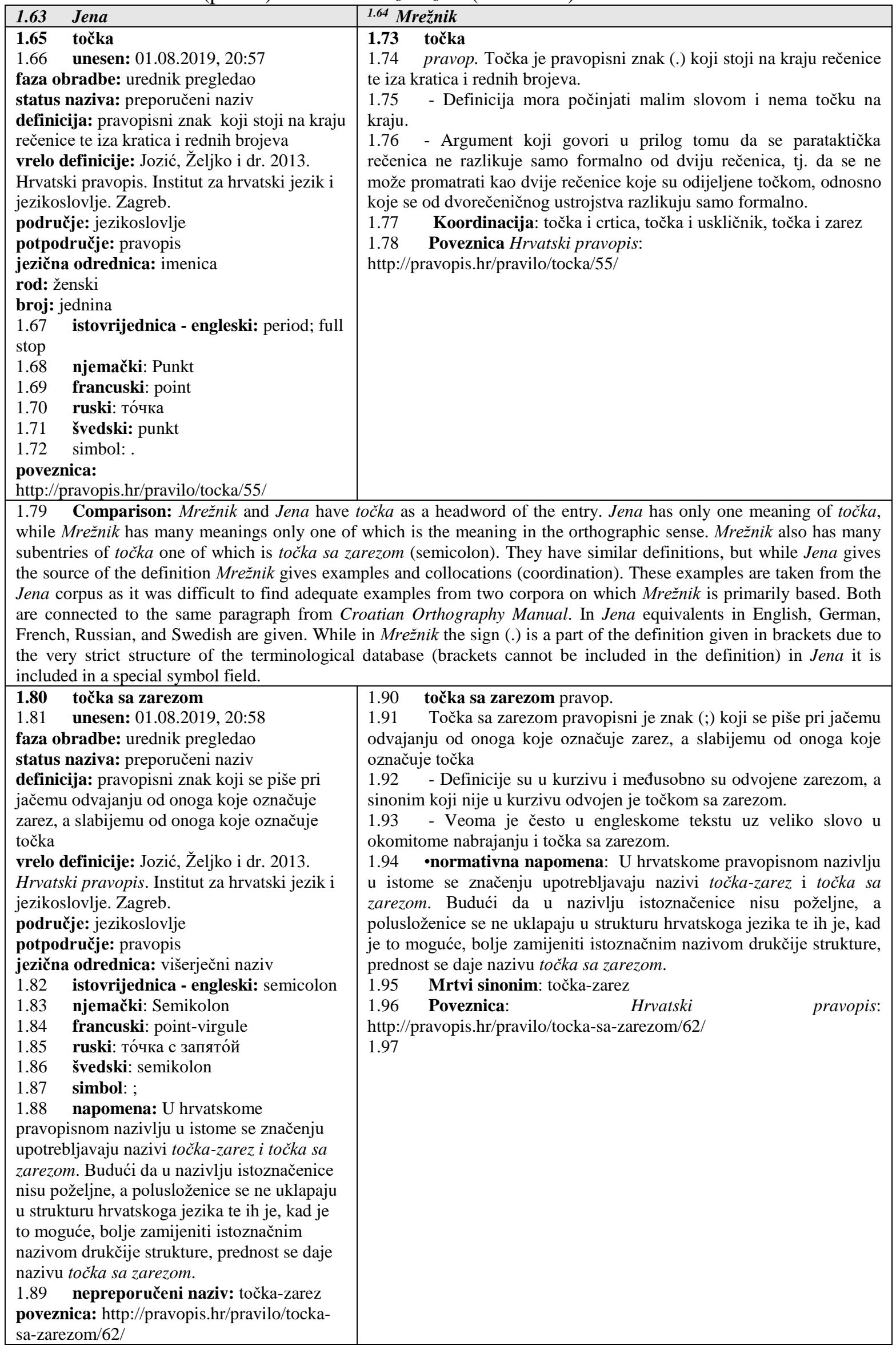


1.98 Comparison: In Jena točka sa zarezom (semicolon) is an entry while in Mrežnik it is a subentry of the entry tockka. The reason for this is that a multiword term has the same terminological status as a single word term. They have similar definitions but only Jena states that the source of the definition is the Croatian Orthographic Manual. Mrežnik gives examples from the corpus while Jena has no examples. Mrežnik gives another synonymous term točka-zarez as a „dead synonym” which means it is not an entry in Mrežnik. In Jena there are no synonymous entries and točka-zarez is given as a non-preferred term. Both sources give the same explanation why točka sa zarezom is preferred to točka-zarez but this explanation occurs in the note field in Jena and in the field normative advice in Mrežnik. However, both are connected to the paragraph on semicolon from the Croatian Orthographic Manual. Both Mrežnik and Jena state that this term belongs to the field of orthography. In Jena equivalents in English, German, French, Russian, and Swedish are given. Examples in Mrežnik are taken from the Jena korpus, as it was difficult to find an adequate example in the two corpora on which Mrežnik is primarily based.

Similar results could be shown when comparing some other entries of general linguistic terms, e.g. imenica (noun), padež (case), sklonidba (declension), sintaksa (syntax).

\section{Glossary of e-lexicography and Jena}

Glossary of E-lexicography compiled within the Mrežnik project and in collaboration with the Jena project consists of names and terms relevant for e-lexicography. This Glossary is an important source for Jena as from it most of the terms (not names) are taken over into the Jena database. In table 3 the comparisons of the entries odostražni rječnik (reversed dictionary) and n-gram is shown in Jena and the Glossary of e-lexicography.

Table 3. Entries odostražni rječnik (reverse dictionary) and n-gram (n-gram) in Jena and Glossary of e-lexicography

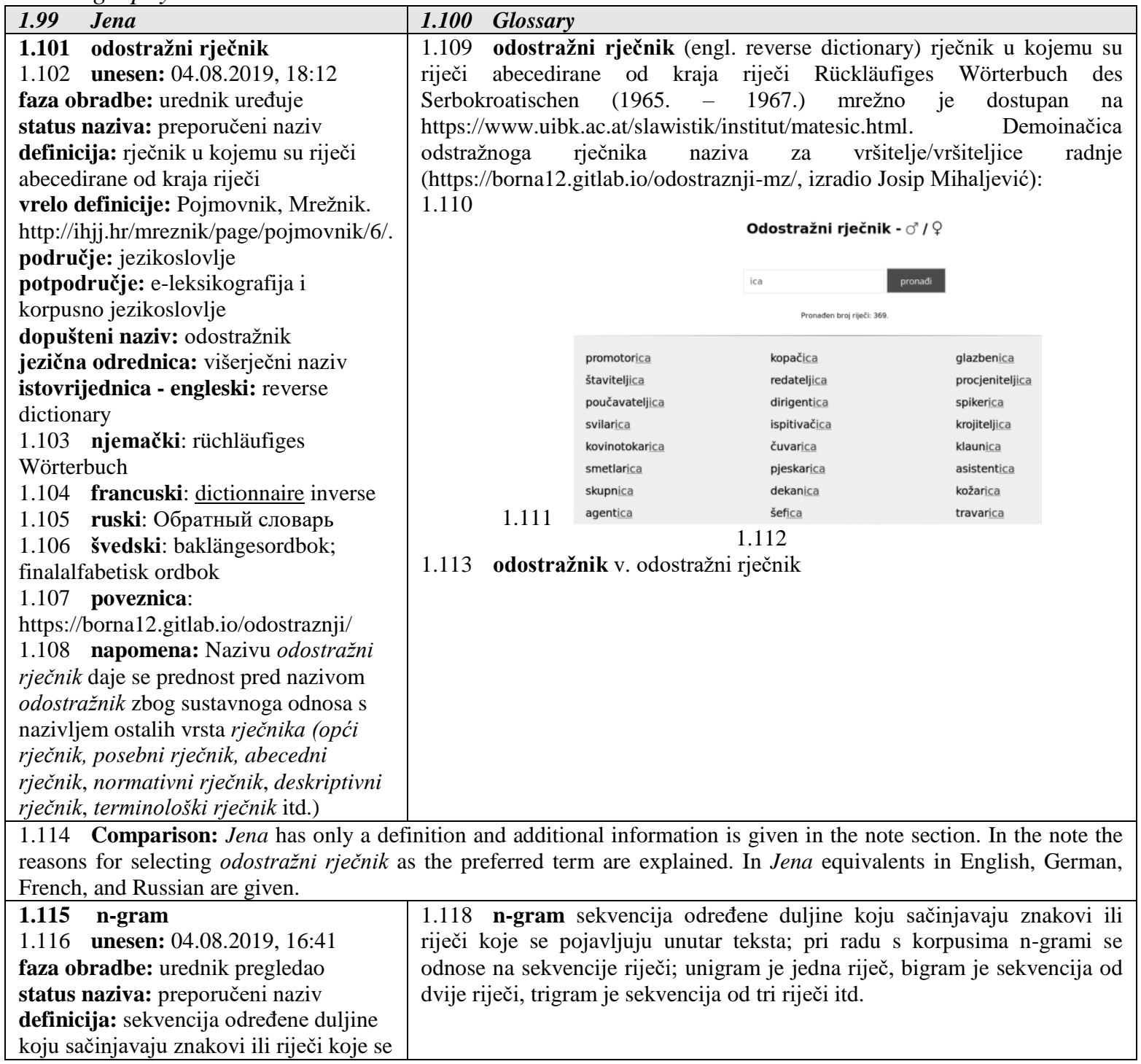


pojavljuju unutar teksta korpusa

vrelo definicije: Pojmovnik, Mrežnik.

http://ihjj.hr/mreznik/page/pojmovnik/6/.

područje: jezikoslovlje

potpodručje: e-leksikografija i

korpusno jezikoslovlje

podređeni pojam: bigram; trigram;

unigram

jezična odrednica: imenica

rod: muški

broj: jednina

istovrijednica - engleski: $n$-gram

istovrijednica - njemački: N-Gramme

istovrijednica - francuski: $n$-gramme

istovrijednica - ruski: $\mathrm{N}$-грамма

1.117 švedski: $n$.gram

1.120 Comparison: In Jena unigram, bigram, and trigram are added as subordinate terms and they have a separate definition. In the Glossary they are explained under $n$-gram but also have separate definitions in the glossary. The Glossary is added as a source in Jena. In Jena equivalents in English, German, French, Russian, and Swedish are given.

\section{Jena vs. Mrežnik: entry structure}

From the general structure of Struna these fields have been activated for Jena (Table 4).

Table 4. Fields in Jena

\begin{tabular}{|l|l|}
\hline $\mathbf{1 . 1 2 1}$ Field & $\mathbf{1 . 1 2 2}$ Explanation \\
\hline 1.123 entry word & 1.124 can be a multiword entry \\
\hline 1.125 grammatical data & 1.126 only word class and gender and number for nouns \\
\hline 1.127 definition & $\begin{array}{l}1.128 \text { with genus proximum and differentia specifica, not a whole sentence, starts } \\
\text { with she small letter and does not end with a period; one term can have only one } \\
\text { definition. }\end{array}$ \\
\hline 1.129 field, discipline & $\begin{array}{l}1.130 \text { subfields of linguistics, e.g. generative linguistics, cognitive linguistics, } \\
\text { pragmatics, etc. }\end{array}$ \\
\hline 1.131 synonyms & $\begin{array}{l}1.132 \text { divided into preferred terms, allowed terms, depicted terms, obsolete terms, } \\
\text { and jargon terms }\end{array}$ \\
\hline $\begin{array}{l}1.133 \text { antonyms (added for the } \\
\text { purpose of this project) }\end{array}$ & 1.134 defined in Jena by a similar definition \\
\hline 1.135 subordinate terms & 1.136 defined in Jena \\
\hline 1.137 source of the definition & $\begin{array}{l}1.138 \text { if the definition was taken over from a source and not formed by the } \\
\text { compiler the source should be stated }\end{array}$ \\
\hline $\begin{array}{l}1.139 \text { equivalents in English, } \\
\text { Russian, French, German }\end{array}$ & 1.140 written (or checked) by experts for each of the languages \\
\hline 1.141 abbreviation or acronym & 1.142 given if any \\
\hline $\begin{array}{l}1.143 \text { connected to other } \\
\text { sources }\end{array}$ & $\begin{array}{l}1.144 \text { the entries are often connected to the Croatian Orthographic Manual or } \\
\text { Croatian School Grammar, sometimes they are connected to other sources, e.g. } \\
\text { articles in the journal Hrvatski jezik }\end{array}$ \\
\hline 1.145 note & 1.146 in the note relevant additional information is given \\
\hline $\begin{array}{l}1.147 \text { phase in the compilation } \\
\text { process are recorded }\end{array}$ & $\begin{array}{l}1.148 \text { different phases are: written by the author, checked by the editor, checked by } \\
\text { the terminologist, checked by the language editor, finished }\end{array}$ \\
\hline
\end{tabular}

The diagram of the structure of Mrežnik is described in detail in Hudeček, Mihaljević, 2019a. In table 5 the main differences between the structure of Jena and Mrežnik are shown:

Table 5. Differences between the structure of Jena and Mrežnik

\begin{tabular}{|l|l|}
\hline $\mathbf{1 . 1 4 9}$ Jena & $\mathbf{1 . 1 5 0}$ Mrežnik \\
\hline $\begin{array}{l}1.151 \text { headword - can be } \\
\text { multiword, not accentuated }\end{array}$ & 1.152 no multiword headwords, headwords and forms are accentuated \\
\hline $\begin{array}{l}1.153 \text { grammatical data, word } \\
\text { class or multiword - for nouns } \\
\text { gender and number }\end{array}$ & 1.154 gives much more grammatical data as well as accentuated forms \\
\hline $\begin{array}{l}1.155 \text { definition - one headword } \\
\text { has only one definition, if needed } \\
\text { the same headword has multiple } \\
\text { entries }\end{array}$ & $\begin{array}{l}1.156 \text { a headword can have multiple senses and definitions. very often the same } \\
\text { entry has many meanings and only one belongs to the field of linguistics (e.g. } \\
\text { crtica, točka, atribut) and sometimes the same word has more than one meaning in } \\
\text { the field of linguistics (e.g.pravopis, rječnik, fonologija) }\end{array}$ \\
\hline
\end{tabular}




\begin{tabular}{|l|l|}
\hline $\begin{array}{l}1.157 \text { field, discipline, has a list } \\
\text { of disciplines and sub-disciplines }\end{array}$ & $\begin{array}{l}1.158 \text { differentiates between linguistics, grammar and orthography, doesn't } \\
\text { differentiate between sub-disciplines }\end{array}$ \\
\hline $\begin{array}{l}1.159 \text { synonyms - differentiates } \\
\text { between the preferred term, } \\
\text { allowed term, non-preferred term, } \\
\text { obsolete term, and jargon term }\end{array}$ & $\begin{array}{l}1.160 \text { gives synonyms, differentiates between synonyms that are dictionary } \\
\text { entries and that are not (synonyms and dead synonims), doesn't differentiate } \\
\text { between the status of synonyms }\end{array}$ \\
\hline $\begin{array}{l}1.161 \text { antonyms - all given } \\
\text { antonyms are dictionary entries }\end{array}$ & $\begin{array}{l}1.162 \text { differentiates between antonyms which are dictionary entries and which } \\
\text { are not (dead antonyms) }\end{array}$ \\
\hline $\begin{array}{l}1.163 \text { subordinate terms - a very } \\
\text { important field for building the } \\
\text { terminological system }\end{array}$ & 1.164 sometimes gives subordinate terms \\
\hline 1.165 source of the definition & 1.166 doesn't give data on the source of definition \\
\hline $\begin{array}{l}1.167 \text { equivalents in English, } \\
\text { Russian, French, German, and } \\
\text { Swedish }\end{array}$ & 1.168 doesn't have equivalents in foreign languages \\
\hline $\begin{array}{l}1.169 \text { abbreviation or acronym } \\
\text { given in a separate field }\end{array}$ & $\begin{array}{l}1.170 \text { abbreviations and acronyms are given as synonyms and not in a separate } \\
\text { field }\end{array}$ \\
\hline $\begin{array}{l}1.171 \text { symbols are given in a } \\
\text { separate field }\end{array}$ & 1.172 symbols, if needed, are included in the definition \\
\hline $\begin{array}{l}1.173 \text { connected to other sources } \\
\text { mostly connected to Croatian }\end{array}$ & 1.174 connected to a number of sources \\
$\begin{array}{l}\text { School Grammar, articles from } \\
\text { the journal Hrvatski jezik and } \\
\text { Croatian Orthography Manual }\end{array}$ & \\
\hline $\begin{array}{l}1.175 \text { additional information } \\
\text { given in the note }\end{array}$ & $\begin{array}{l}1.176 \text { differentiates between the pragmatic note and the normative note } \\
\text { (language advice) }\end{array}$ \\
\hline $\begin{array}{l}1.177 \text { records the phase in the } \\
\text { compilation process }\end{array}$ & 1.178 doesn't state explicitly the phase in the compilation process \\
\hline $\begin{array}{l}1.179 \text { context } \\
1.180 \text { examples and collocations }\end{array}$ \\
\hline
\end{tabular}

An important difference between Mrežnik and Jena is the approach to collocations. In Mrežnik they have a separate field where they are introduces by questions, e.g. What is xxx like?, What does xx do?, What can we do with xxx?, Coordination, What is mentioned in connection with xxx? In Jena there is no special collocation field and they can be either introduced as subordinate terms which than have separate entries, explained in the note or ignored.

\section{Results of the comparison}

The results of the comparison prove the hypothesis that two such projects as Jena and Mrežnik can be compared and that they can mutually profit from each other and such a comparison. The results of the comparison are shown in table 6.

Table 6. Comparison of Jena and Mrežnik

\begin{tabular}{|c|c|c|c|}
\hline $\begin{array}{l}\text { Points of } \\
\text { comparison }\end{array}$ & Mrežnik & Jena & Benefits \\
\hline wordlist/termlist & $\begin{array}{l}\text { terms extracted from } \\
\text { the two corpora and } \\
\text { supplemented by the } \\
\text { lexicographers }\end{array}$ & $\begin{array}{l}\text { termlist compiled } \\
\text { by field specialists } \\
\text { and supplemented } \\
\text { by corpus data }\end{array}$ & $\begin{array}{l}\text { Mrežnik wordlist was checked against the Jena } \\
\text { termlist and all terms belonging to general } \\
\text { vocabulary are included into Mrežnik } \\
\text { Jena termlist was supplemented by the terms } \\
\text { from the Glossary of e-lexicography }\end{array}$ \\
\hline corpus & corpus-based & $\begin{array}{l}\text { corpus-based } \\
\text { (but the role of the } \\
\text { corpus is not as } \\
\text { important as in } \\
\text { Mrežnik) }\end{array}$ & $\begin{array}{l}\text { for linguistic terms in Mrežnik examples can be } \\
\text { taken form the Jena corpus }\end{array}$ \\
\hline normativity & $\begin{array}{l}\text { normative dictionary, } \\
\text { normativity } \\
\text { expressed in the } \\
\text { normative advice } \\
\text { note }\end{array}$ & $\begin{array}{l}\text { differentiates } \\
\text { between preferred, } \\
\text { allowed, non- } \\
\text { preferred, obsolete, } \\
\text { and jargon terms }\end{array}$ & $\begin{array}{l}\text { normative advice given in Mrežnik and in Jena is } \\
\text { always the same (it can be explained differently), } \\
\text { i.e. once the normative status of a term is } \\
\text { determined within one project the same } \\
\text { normative status is given to the term in the other }\end{array}$ \\
\hline
\end{tabular}

\footnotetext{
${ }^{5}$ See in Hudeček, Mihaljević 2017c; Jozić et al., 2013.
}

${ }^{6}$ See Hudeček and Mihaljević in print. 


\begin{tabular}{|l|l|l|l|}
\hline $\begin{array}{l}\text { the structure of } \\
\text { dictionary entries }\end{array}$ & $\begin{array}{l}\text { The structure of } \\
\text { dictionary entries is } \\
\text { determined by the } \\
\text { project head in } \\
\text { collaboration with } \\
\text { project members }\end{array}$ & $\begin{array}{l}\text { the structure is } \\
\text { only partially } \\
\text { flexible as it is } \\
\text { limited by the }\end{array}$ & $\begin{array}{l}\text { projects have different structure but all relevant } \\
\text { data determined by the research on either of the } \\
\text { projects could be included into the other project; } \\
\text { the experience on Mrežnik resulted in the } \\
\text { inclusion of the field antonyms in Jena }\end{array}$ \\
\hline
\end{tabular}

\section{Conclusion}

The aim of this paper is to show how two projects conducted at the same time in the same institution can influence each other and how experience with one project as well as the corpus and data from one project can help the other project. As we started working on this paper at the very beginning of Jena, this gave us the perfect opportunity to test the hypotheses that the work on a terminological project can help the work on a general e-lexicographic project as well as benefit from it. Despite many differences, Mrežnik and Jena are closely connected as the Glossary of E-lexicography serves as one of the sources for Jena and as some definitions of general linguistic and orthographic terms from Mrežnik can serve as a starting point for composing the entry of the same headword in Jena (as shown above). We also found the corpus compiled for Jena very useful for collocations and examples in Mrežnik as with some frequently used words which have many meanings in the general language (as for example točka shown above as well as čestica, prilog, prijedlog) it was difficult to find the adequate example in the general corpus.

At the end of Jena, entries from Mrežnik will be connected with external links to entries in Jena as is Mrežnik already connected to some other finished Struna projects. Some other projects conducted at the Institute are connected to one or both of the analysed projects, e.g. the project Orthographic Manual of Religious Terminology is connected with Mrežnik as religious terms also form an important part of Mrežnik. The project Male and Female in the Croatian Language is strongly connected to both of the analysed projects as in Mrežnik each noun denoting a male person is connected to the noun denoting a female person ${ }^{7}$ and in Jena special attention is paid to professional nouns in the field of linguistics (male and female).

\section{Acknowledgments}

This paper is written within the research project Croatian Web Dictionary - MREŽNIK (IP-2016-062141) and the project Croatian Linguistic Terminology - Jena (Struna-2017-09-05), both financed by the Croatian Science Foundation.

\section{References}

Hudeček, L. (2018). Izazovi leksikografske obrade u jednojezičnome mrežnom rječniku (na primjeru Hrvatskoga mrežnog rječnika - Mrežnika). // Visnyk of Lviv University: Series Philology 69, 29-38

Hudeček, L., Mihaljević, M. (2017a). A New Project - Croatian Web Dictionary MREŽNIK. // The Future of Information Sciences. INFuture2017, Integrating ICT in Society / Atanassova, I. et al. (eds.). Zagreb: Department of Information and Communication Sciences, Faculty of Humanities and Social Sciences, 205-213

Hudeček, L., Mihaljević, M. (2017b). Hrvatski mrežni rječnik - Mrežnik. // Hrvatski jezik 4, 4, 1-7

Hudeček, L., Mihaljević, M. (2017c). Školska gramatika hrvatskoga jezika. Zagreb: Institut za hrvatski jezik i jezikoslovlje

Hudeček, L., Mihaljević, M. (2018a). Croatian Web Dictionary Mrežnik: One year later - What is different? // Proceedings of the Conference on Language Technologies \& Digital Humanities / Fišer, D., Pančur, A. (eds.). Ljubljana: Oddelek za prevajalstvo, Inštitut za novejšo zgodovino, 106-113

Hudeček, L., Mihaljević, M. (2018b). Hrvatski mrežni rječnik - Mrežnik: Upute za obrađivače. http://ihjj.hr/mreznik/uploads/upute.pdf (27.10.2019)

Hudeček, L., Mihaljević, M. (2019a). Croatian Web Dictionary - Mrežnik - Linking with Other Language Resources. // Electronic lexicography in the 21st century - Proceedings of the eLex 2019 conference / Kosem, I. et al. (eds.). Leiden: Lexical Computing CZ s.r.o, 72-98

Hudeček, L., Mihaljević, M. (2019b). Profesijski nazivi u hrvatskoj e-terminografiji i e-leksikografiji. // Studia lexicographica $13,24,75-95$

Institut za hrvatski jezik i jezikoslovlje. Glossary of E-lexicographic Terminology. 14.10.2019. http://ihjj.hr/mreznik/page/pojmovnik/6/ (30.08.2019)

Institut za hrvatski jezik i jezikoslovlje. (2019). Hrvatsko jezikoslovno nazivlje - Jena. 23.10.2019. http://ihjj.hr/jena/ (30.08.2019)

\footnotetext{
${ }^{7}$ More on the topic see in Hudeček, Mihaljević, $2019 \mathrm{~b}$.
} 
L. Hudeček, M. Mihaljević. Croatian Web Dictionary...

Institut za hrvatski jezik i jezikoslovlje. (2010). Hrvatsko strukovno nazivlje - Struna. 16.09.2010. http://struna.ihjj.hr/ (30.08.2019)

Institut za hrvatski jezik i jezikoslovlje (2017). Muško i žensko u hrvatskome jeziku. 1.11.2017. http://ihjj.hr/projekt/muskoi-zensko-u-hrvatskome-jeziku/72/ (20.08.2019)

Institut za hrvatski jezik i jezikoslovlje. Religijski pravopis. 5.11.2015. http://hjj.hr/projekt/religijski-pravopis/23/ (20.08.2019)

Jozić, Ž. et al. (2013). Hrvatski pravopis. Zagreb: Institut za hrvatski jezik i jezikoslovlje 